\title{
DETERMINANTS OF GREEN BUYING BEHAVIOUR
}

\author{
Bhagyasree $\mathbf{R}$ \\ Assistant Professor, Sree Sabareesha College, Mundakayam, Punchavayal, Kerala, India
}

\begin{abstract}
Green consumers are considered to take an ownership of environment betterment. But certainly not only on the name of green products this ownership can be commercialized. This study tries to identify and the elements which determine the buying behavior of green consumers and also test their level of association with green purchase. To check this, a multiple regression analysis has been conducted taking ecolabeling, green branding, environmental advertising, green pricing, eco-image, environmental concerns and beliefs as independent variables and green buying as dependent variable. The study found green branding and green pricing to be the significant variables affecting the behavior of green customers.
\end{abstract}

Key words: Green consumers, green branding, green pricing, eco labeling

Cite this Article: Bhagyasree R, Determinants of Green Buying Behaviour, International Journal of Management (IJM), 11(12), 2020, pp. 3117-3122.

http://iaeme.com/Home/issue/IJM?Volume=11\&Issue=12

\section{INTRODUCTION}

Green marketing, also called sustainable marketing, is effort of corporate at planning and promoting, goods and services not to damage the environment. One of the original explanations of green marketing covers both affirmative and undesirable activities and study of the reduction in energy and non-energy sources, toxicity etc. (Henoin, 1972). The latest definition is totally advanced with reference to variables. It believes that green marketing includes those strategies of marketing which help organizations to achieve financial and strategic aims mitigating its undesirable effect on the surroundings (Leonidou et al., 2013). People throughout the world are worried about the environment and are altering their lifestyle. Consequently, green marketing emerged as an alternative in rising market for green products and services. Therefore, the consciousness amid the customers around the world regarding safety of the environment is growing. People wish to confer on an unpolluted earth to the offspring. Now the consumers are interested in environment friendly products.

Dahlstorm (2011) and Ottman (2011) have considered green marketing as a combination of ecological apprehensions into marketing characteristics such as production, supply, pricing, packaging and communication mix. The studies done on green purchasing behavior and attitudes of the diverse people found that green marketing gained importance in developing 
countries (Khare, 2014). It was also concluded that components which have an influence on green consumptions are, consciousness and information related to green goods, confidence in eco-brands, consumers' anxiety concerning environment's degradation and their selfless values (Srivastava, A, 2020).

To predict the market segmentation better for green goods, it is vital to measure the effect of factors that encourage green behavior in customers turning to green purchases. The decisionmaking process of customers' is influenced by a number of factors, utmost is consumer's awareness and knowledge related to green products commands over all other (Carlson et al., 1993). To understand the idea of green marketing, one should know a green consumer. Elkington (1994) describes a green shopper as a person who avoids using products that threaten the environment owing to their production or disposing methods, or goods that comprise animal brutality or goods that are found from endangered species.

\section{LITERATURE REVIEW}

Juwaheer et al., (2012) stated a number of variables of consumer beliefs that drives green behavior. Overtime, many researchers have further investigated on ecological matters and conservation with respect to markets across the world (Mintel, 2006). It is important to examine green buying activities of green consumers to identify the factors that drive the consumer purchase patterns. It also includes the purchase intent and real buying behavior of green products. Grob(1995) describes behavior in environmental framework as activities that directly affect the ecosystem. There are numerous green practices that are gaining momentum like recycling, saving paper and electricity, inspiring usage of green products (Gilg et al., 2005). Customers call for green drive is regularly moving upwards (Han et al., 2010). It could be due to consumers' understanding of the effect which their conduct has on the environment. PickettBaker and Ozaki (2008) witnessed an association amid consumers' green beliefs and the assurance on the performance of eco-friendly products. Young et al. (2010) recommended a gap in between "attitude-behavior" in decoding consumers' environmental apprehensions into behavior.

In developing countries like Malaysia, Singapore and Mauritius, it was observed that ecofriendly consumption gained popularity. The variables that drove such expenditures were wakefulness and acquaintance of green goods, belief in eco-brands, and consumers' anxiety to environment's deprivation. The customers remained more united socially and prefer a multicultural and favorable attitude to green goods (Mostafa, 2009, Rahbar and Wahid, 2011 and Juwaheer et al., 2012).

In India, contrary opinions were found by different researchers. Singh and Pandey (2012) found that Indian customers show an improved interest in green goods. If the clients are properly aware of the cost, value, features, performance and benefits of various eco goods, it gives rise to the use of such goods. The study also suggested that in India, customers lack knowledge of natural/sustainable goods which includes recyclable products, organic/natural food etc. and therefore green products developments and brand awareness should be promoted. However study by Mishra and Sharma (2010) found Ayurveda and herbal goods which are admired in India since years are considered significant as they comprise of natural elements and medicinal aids. They are believed to be free from any side effect so encouraging them they are often used at home for beauty benefits. Globalization has greatly affected the usage of resources which resulted in modification of lifestyles of green consumers. Considering the facts from the literature, further examination on the Indian consumers by finding the association between consumer belief and behavior may give better insights. 


\section{RESEARCH METHODOLOGY}

As this study aims to study the relation between Environmental behavior (dependent variable) and independent variables eco-labeling, green branding and packaging, environmental advertising, green pricing, eco-image, environmental concerns and beliefs, so a questionnaire has been used to measure the variables. The questionnaire in this research is taken from Juwaheer et al. (2012) which is divided into seven parts-

\section{DEFINITION OF VARIABLES:}

Green Buying behavior: Grob (1995) has defined green buying behavior as acts that directly cause an impact on the environment. It's necessary to examine green buying behavior of people to understand the variables that motivate the consumer buy behavior along with purchase intention and actual purchase behavior of green products.

Green branding and packaging: Banytè \& Gadeikienè (2008) considered that recently, green marketing is highlighted as a tool contributing to sustainable growth and enhancing the brand image. Marketing of ecological products is commercially difficult if there exists a gap in communicating brand attributes (Meffert and Kirchgeorg, 1993). It is believed to have positive association with environmental behavior.

Eco-labeling: Eco-labeling imposes on the purchase behavior of eco products. As per Global Eco-labeling Network (2004), an eco-label identifies whole ecological inclination of goods or services in a product categorization related to its life cycle. It is believed to have positive association with environmental behavior

\section{Green Pricing}

Ali and Ahmad (2012) suggested that companies tend to take benefit from green products and services markets especially from consumers that attach value to such goods due to their contributions to preservation of energy and environment. It is believed that people are ready to pay high price for green products and hence a positive relation is expected.

Green advertisements: Consumer activist and public, in late 1960s raised the concern about firms using anti-environmental practices. The green advertising has declined due to fake claims through advertisements, exaggeration into content of advertisement and it was followed by making consumers' confused about the jargons used (Polonsky et al., 1997). It is expected to have positive association with environmental behavior.

Eco-image: The organic or natural company image is considered to be significant factor in the present business setup. Bathmanathan and Hironaka (2016) found that stakeholder's eco friendly perception of the business enhances business growth. It is expected to have positive association with environmental behavior.

Environmental concerns and beliefs: The activities necessary to reduce and monitor adverse effects on the environment to comply with the laws. Milfont (2007) suggested that environmental approaches cause environmental behaviors which is a mental tendency articulated by examining the natural atmosphere with some level of likes or dislikes.

\section{Hypotheses:}

Hypothesis (a): There is a positive association between eco-labeling and green buying.

Hypothesis (b): There is a positive association between green branding and the green buying.

Hypothesis (c): There is a positive association between green advertising and the green buying.

Hypothesis (d): There is a positive association between green pricing and the green buying. Hypothesis (e): There is a positive association between eco-image and the green buying. 
Hypothesis (f): There is a positive association between environmental concerns and beliefs and the green buying.

\section{DATA COLLECTION AND SAMPLE}

The responses were collected on a 5-point Likert scale between 1 and 5 (1=Strongly Disagree, $2=$ Disagree, $3=$ Neutral, 4=Agree and 5=Strongly Agree). It comprised of around 29 statements which were analyzed using multiple regression analysis. The respondents were the visitors of organic stores situated in various areas of Delhi NCR. A sample of around 200 respondents was selected and the questionnaire was self-administered. A random sampling was conducted.

The questionnaire was first pilot tested for reliability and validity using a sample of around 40 respondents. The reliability statistics are presented below:

Table 1 Reliability statistics

\begin{tabular}{|l|l|}
\hline Factors & Chronbach Alpha \\
\hline Green buying behavior & 0.826 \\
\hline eco-labelling & 0.692 \\
\hline green branding and packaging & 0.735 \\
\hline green pricing & 0.714 \\
\hline green advertising & 0.793 \\
\hline eco-image & 0.812 \\
\hline environmental concerns and beliefs & 0.801 \\
\hline Over all & 0.668 \\
\hline
\end{tabular}

\section{REGRESSION ANALYSIS}

In regression analysis, the dependent variable is forecasted through independent variables. The regression model for this analysis is:

Green buying behavior $=a+\beta E L+\beta G B P+\beta E A d+\beta G P+\beta E I+\beta E C B+e$

Where, green buying behavior is the endogenous variable $\alpha$ is intercept and $\beta$ measures the changes in dependent variable due to independent variables which are EL- eco-labeling GBgreen branding, EAd- environmental advertising GP- green pricing EI- eco-image ECBenvironmental concerns and beliefs; e is error term

Table 2 shows the correlation between the distinct factors of environmental beliefs and green buying behavior using spearman's test.

Table 2 Correlations

\begin{tabular}{|l|c|r|}
\hline Variables & Coefficient & Significance \\
\hline Eco-labelling and green products identification & $.320^{*}$ & 0.027 \\
\hline Green branding for ecological customers & $.316^{* *}$ & 0.005 \\
\hline $\begin{array}{l}\text { Environmental advertisement and green } \\
\text { consumption patterns }\end{array}$ & 0.13 & 0.261 \\
\hline $\begin{array}{l}\text { Importance of green products and premium } \\
\text { green pricing }\end{array}$ & $.415^{* *}$ & 0.001 \\
\hline $\begin{array}{l}\text { Embedding an eco-image in marketing of } \\
\text { green products }\end{array}$ & 0.065 & 0.572 \\
\hline $\begin{array}{l}\text { Consumers' perceptions on environmental } \\
\text { concerns and beliefs }\end{array}$ & 0.032 & 0.799 \\
\hline
\end{tabular}


Bhagyasree R

Table 3 Regression Analysis

\begin{tabular}{|l|l|l|l|}
\hline \multicolumn{1}{|c|}{ Variables } & Beta & Significance & VIF \\
\hline Eco labelling & 0.109 & 0.305 & 2.45 \\
\hline Intensity Green Branding & 0.438 & $0.016^{*}$ & 3.27 \\
\hline Environmental Advertising & 0.024 & 0.945 & 1.89 \\
\hline Green Pricing & 0.366 & $0.044^{*}$ & 2.36 \\
\hline Eco Image & 0.18 & 0.319 & 1.12 \\
\hline Environmental concern & -1.321 & 0.122 & 3.81 \\
\hline $\mathrm{R}^{2}$ & 0.312 & & \\
\hline Adjusted $\mathrm{R}^{2}$ & 0.252 & & \\
\hline Anova (F value) & & & \\
\hline
\end{tabular}

The table 3 of multiple regression analysis indicates that the factor green branding and green pricing are as per the hypotheses that these two factors have positive and significant impact on environmental buying as the coefficients 0.438 and 0.366 are significant at 5 percent. The variable environmental concern with coefficient -1.321 is negative and insignificant $(0.122)$ which suggests that only concern is not going to help until it is applied. The eco labelling and eco-image have coefficient value of 0.109 and 0.18 respectively which are insignificant, but the signs are as per expectations. The adjusted $\mathrm{R}$ square value of 0.256 is low but as per Gujrati () the low $\mathrm{R}$ square is acceptable if the $\mathrm{F}$ value is significant and the variables are not correlated.

\section{CONCLUSION}

This research was to investigate the impact of green marketing elements on the consumer buying behavior in India. The study is done on a sample from Delhi NCR in India. The analysis suggests that consumer perception of the intensity of green branding is significantly and positively associated with environmental behavior of customers and hence a straight linkage amid branding and consumer behavior is there which adds to the green purchase patterns. It is believed that people incline towards known brands. The study also found that consumers know the significance of green goods and that's why premium green pricing a positive and significant impact on the green behavior of consumers has, further leading to their purchase patterns. In terms of correlations, weak but significant positive correlations were found between consumer perceptions of effectiveness of eco-labelling and green consumer behavior. Apart from this, some other interesting results were found but were not statistically significant. Based on the results, it was gathered that effectiveness of eco-labelling had a positive effect on the consumers environmental behavior.

\section{REFERENCES}

[1] Afzaal Ali, A. and Ahmad, I. (2012), Environment Friendly Products: Factors that Influence the Green Purchase Intentions of Pakistani Consumers, Pak. j. eng. technol. sci. 2(1)

[2] Bathmanathan, Vathana \& Hironaka, Chikako, (2016)." Sustainability and business: what is green corporate image?”. Earth and Environmental Science ,32.

[3] Carlson, L., Grove, S.J. and Kangun, N. (1993) 'A content analysis of environmental advertising claims: A matrix method approach', Journal of Advertising, 22(3), pp. 27-39. doi: 10.1080/00913367.1993.10673409.

[4] Dahlstorm, R. (2011) Green Marketing: Theory Practice and Strategy. Cengage Learning India edition. 
[5] Elkington, J. (1994) 'Towards the sustainable corporation: Win-win-win business strategies for sustainable development', California Management Review, 36(2), pp. 90-100. doi: $10.2307 / 41165746$

[6] Gilg, A., Barr, S. and Ford, N. (2005) 'Green consumption or sustainable lifestyles? Identifying the sustainable consumer', Futures, 37(6), pp. 481-504. doi: 10.1016/j.futures.2004.10.016

[7] Grob, A. (1995) 'A structural model of environmental attitudes and behaviour', Journal of Environmental Psychology, 15(3), pp. 209-220. doi: 10.1016/0272-4944(95)90004-7.

[8] Han, H., Hsu, L.T. and Sheu, C. (2010) 'Application of the theory of planned behavior to green hotel choice: Testing the effect of environmental friendly activities', Tourism Management, 31(3), pp. 325-334. doi: 10.1016/j.tourman.2009.03.013.

[9] Juwaheer, T., Pudaruth, S. and Monique Emmanuelle Noyaux, M. (2012) 'Analysing the impact of green marketing strategies on consumer purchasing patterns in Mauritius', World Journal of Entrepreneurship, Management and Sustainable Development, 8(1), pp. 36-59. doi: $10.1108 / 20425961211221615$

[10] Khare, A. (2014) 'Antecedents to green buying behaviour: A study on consumers in an emerging economy’, Marketing Intelligence \& Planning, 33(3), pp. 309-329. doi: 10.1108/mip-05-20140083 .

[11] Leonidou, C.N., Katsikeas, C.S. and Morgan, N.A. (2013) “"Greening” the marketing mix: Do firms do it and does it pay off?', Journal of the Academy of Marketing Science, 41(2), pp. 151170. doi: 10.1007/s11747-012-0317-2.

[12] Meffert,H.andKirchgeorg,M.(1993),Marktorientiertes Umweltmanagement,SchaefferPoeschel, Stuttgart.

[13] Mintel (2006) Green living, US Marketing Research Report. London.

[14] Mishra, P. and Sharma, P. (2010) 'Green Marketing in India: Emerging Opportunities and Challenges', Journal of Engineering, Science \& Management Education, 3, pp. 9-14.

[15] Mostafa, M.M. (2009) 'Shades of green: A psychographic segmentation of the green consumer in Kuwait using self-organizing maps', Expert Systems with Applications, 36(8), pp. 1103011038. doi: 10.1016/j.eswa.2009.02.088.

[16] Ottman, J. (ed.) (2011) The New Rules of Green Marketing: Strategies Tools and Inspiration for Sustainable Branding. Greenleaf Publishing

[17] Pickett-BakerJosephine and Ozaki, R. (2008) 'Pro-environmental products: Marketing influence on consumer purchase decision', Journal of Consumer Marketing, 25(5), pp. 281-293. doi: 10.1108/07363760810890516.

[18] Polonsky, M.J., Carlson, L., Grove, S. and Kangun, N. (1997) 'International environmental marketing claims', International Marketing Review, 14(4), pp. 218-232. doi: 10.1108/02651339710173426.

[19] Rahbar, E. and Abdul Wahid, N. (2011) 'Investigation of green marketing tools effect on consumers purchase behaviour', Business Strategy Series, 12(2), pp. 73-83. doi: $10.1108 / 17515631111114877$

[20] Singh, P.B. and Pandey (2012) 'Green Marketing:policies and practices for sustainable development', Integral Review -A Journal of Management, 5(1).

[21] Srivastava, A., Sharma, R. K., \& Suresh, A. (2020). Impact of Covid-19 on sustainable development goals. Int. J. Adv. Sci. Technol, 29, 253-258. 